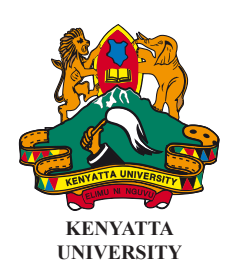

ISSN 1563-1028

\section{CHEMCHEMI}

International Journal of Humanities and Social Sciences

\title{
CULTURAL IMPERATIVES FOR SUSTAINABLE DEVELOPMENT IN NIGERIA
}

\author{
Emmanuel Jegede
}

\begin{abstract}
Most development interventions at local and national levels in Nigeria apparently lack cultural relevance and sensitivity, and consequently, end up a big failure. Culture is an essential force in the proper planning of development initiatives. Researchers and policy-makers have underscored the importance of cultural knowledge as it augments our understanding of development issues and strategies to enhance their sustainability in Africa. The interrogation of the current approaches to sustainable development from a cultural perspective is critical to achieving balanced development. Culture is necessary in order to give purpose and credibility to one's own existence. Rob people of their culture and you rob them of their reason of being. It is imperative that cultural factors be integrated into the current discourses and strategies for enhancing sustainable development if the resulting outcomes are to be relevant to the realities of African societies and facilitate improvements in the quality of life and wellbeing of the people. Using desk research, interview technique and practical experiences, the paper examines the centrality of cultural approaches to development intervention in Nigeria (Africa) in view of the international call for an inclusive development strategy to enhance sustainability. At the same time, the paper attributes the lack of sustainable development in Nigeria to the imperialistic tendencies of the foreign culture. In the end, the paper makes recommendations on how culture can be handled to make sustainable development happen in Nigeria.
\end{abstract}

Key words: Culture, Ideology, Sustainable development, Nigeria, Cultural tools, Cultural imperialism

\section{Introduction}

Sustainable development is multifaceted and is determined by a complex web of factors. Musaazi (1986) observes that no single discipline in Africa can unilaterally claim special insight into the variegated process of development. While education, philosophy, development economics, sociology, religion, history, political science, development communication, science and technology daily seek answers to development problems of a nation, it is pertinent to say that culture plays a key and central role in the realization of effective development in developing countries especially Nigeria. Any development, therefore, planned and articulated outside the culture of a people may end up a failure. The most fundamental error in Nigeria's approach to development planning has been the assumption that socio-economic and political development can be pursued along capitalist lines without putting into consideration the local cultural and institutional paraphernalia, In Nigeria, conscious efforts have not been made to promote and facilitate the cultural communication, practices and value systems which of necessity, must emerge in reaction to the capitalist organization of production.

Okwori (2013) asserts that culture and development are so intrinsically linked that planning development interventions without comprehensively embracing culture can be justifiably considered as the greatest bane of development planning. Culture implicates development because both are engaged in the transformation of human society for its well-being. However culture is double-edged: it is both an enabler and an inhibitor to development. As enabler, meaningful development cannot happen without recourse 
to culture, and as inhibitor; cultural practices are responsible for the attitudes and behaviours that cause most development problems. However, it is within this dual contradiction that development planners find the right key to 'cultural legitimacy' that unlocks development success. An-Naim (1990) insists that the crisis of most development efforts lies in the lack of cultural legitimacy, which provides the best platform for realizing development, although he was speaking specifically in terms of human rights, it resonates in the arena of development even more. The greatest cultural tools in the hands of development planners are therefore cultural analysis, and the deployment of creative tools and cultural resources.

In view of the above, an understanding of the inextricable link between culture and sustainable development is important in sensitizing both scholars and policy- makers to the danger of treating culture and development as if they are separate and unrelated spheres in the overall struggle for sustainable development and national transformation. It is therefore, argued in this work that culture, if given its due place, can deliver development to a nation and conversely, its neglect can frustrate any development intervention and constitute a big impediment in the general quest for a new social order. To realize this intention, empirical evidence on how culture implicates development is provided as manifested in the health initiative of the Partnership for Transforming Health Systems 2 (PATHS 2) in Nigeria. Besides, the paper also comes up with some recommendations on how culture can be deployed to facilitate development interventions in Nigeria.

\section{Conceptualizing Culture}

A good understanding of culture is needed if we must establish a viable nexus between it and sustainable development. Vaknin (2005) defines culture as:

the sum total of the ways of life of a people; it includes norms, learned
behaviour patterns, languages, attitudes, and artifacts; also involves
traditions, habits or customs; how people behave, feel and interact; the
means by which they order and interpret the world; ways of perceiving,
relating and interpreting events based on established social norms; a
system of standards for perceiving, believing, evaluating and acting.

Amadi (1981) sees culture as the way of life evolved by a people in its environment - the social, political, economic, aesthetic and religious norms and modes of organization which together distinguish a people from her neighbours. Yere (2007) argues that culture is partly human, spiritual and partly materialistic. In its humanistic aspect, culture consists of ideas, values, knowledge, philosophy, law and morals etc. In its spiritual aspect, it consists of a system of beliefs and religious practices. In its material form, it comprises artifacts and consumer goods made by man as opposed to things found in nature. These definitions offered above help to explain material and non-material aspects of culture. In the same vein, the cultural policy of Nigeria defines culture as:

the totality of the way of life evolved by a people in their attempts to
meet the challenge of living in their environment, which gives order
and meaning to their social, political, economic, aesthetic and religious
norms and modes of organization thus distinguishing a people from
their neighbours.

It is interesting therefore to note that the policy states that culture comprises material, institutional, philosophical and creative aspects. The material aspects referred to include artefacts like tools, clothing, food, medicine, utensils and so on; the institutional deals with the political, social, legal and economic structures created to help achieve the material and spiritual wellbeing of the people; the philosophical aspect is concerned with ideas, beliefs and values; while the creative aspect concerns the people's literature as well as their visual and performing arts, which help to mould other aspects of culture. Thus, culture encompasses arts and other ways of life of a people that give meaning and order to the environment they live in.

Culture is a blueprint for living. Every person is born into an existing culture, which must be learned and which shapes his/her life. This explains why the social scientists see culture as the entire way of 
life within a society. According to Ayakoroma (2011), culture is not merely a return to the customs of the past. It embraces the attitude of a people to the future of their traditional values faced with the demands of modern technology which is an essential factor of development. Culture therefore structures and determines the way social institutions shape life as well as how cultivated and imposed behaviours are communally transmitted from one generation to another. Culture is both evolutionary and revolutionary. Expatiating on this, Soetan (2001) contends that:

culture goes through an internal evolutionary process of change and
adaptation as a result of contact with other cultures, the influence of a
dominant culture and the influence of communication technologies. As
a result, culture must be seen as a dynamic mechanism that must adjust
and adapt to external and internal conditions of existence.

In the furtherance of his argument, Soetan believes that culture humanises development to re-establish its validity and its impact on every domain of human knowledge and practice. Cultural discourse has, therefore, been central to contemporary humanities research and the location of culture and the question of talking back have continued to be a central methodology at the turn of the last millennium. Like other Third World Critics, Homic Bhagha has centred the metaphor of the 'location of culture' as an important approach in modern scholarship. Some critics interrogate development when it does not take on board cultural imperatives. A self-conscious approach to relocate culture becomes a necessity. Without cultural contextualization, some critics including Bhagha, raise fundamental questions such as whose development and what are the motivating factors in development strategies?

Many other critics have also identified the inseparability of culture and development. Culture is considered as a tool for broad-based, qualitative, human-centred and sustainable development. Ayakoroma (2011) for example, notes that cultural definitions are as diverse as its roles but one can aver that culture can be used to liberate, or oppress, to augment or retard human growth and development. This also means that people may entrench the negative or positive images of culture according to their motives and purposes. Culture is not static and the failure to identify the necessity of cultural growth and how it impacts on human experience and development can create conflicts in the lives of individuals or groups.

Ashiwaju and Areola (1995) argue that culture is used to depict, analyze and interpret important aspects of human conduct or behaviour within the society. Culture deals with elements of society such as institutions, values, norms, ideas, ethos, science and technology as well as the attitudes, beliefs and behaviours of individual members of the society. Culture derives from the material and economic base of society which fashions and conditions its elements including its science and technological makeup of individuals in any particular period in history. Culture in a sense, is a reflection of the standards attained in a society in any particular historical epoch. To this end, there is, thus a close relationship between development, historical experiences, events and ideas and the culture of a society.

\section{Subversion of Local Culture and Implications for Sustainable Development}

The subversion of the Nigerian culture by western influences has constituted one of the greatest obstacles to her sustainable development. In fact, most of the discussions and questions on the influence of culture on national development have to focus on this dimension. For example, in this connection, Nkom (1997) asks some ideological questions as follows: How can the positive elements of Nigeria's rich cultural traditions and experiences be revived, preserved and made the basis for a more authentic and humane system of self-reliant and sustainable development? How can the harmful and alien cultural practices and influences which have been imposed on us by colonialism and western imperialism be controlled, curtailed if not completely eradicated? How can we evolve a cultural system which enhances the emergence of those creative, inventive and productive propensities or energies of the people which are absolutely vital for our industrial take-off but which have tended to be suppressed and subverted by colonialist and imperialist influences? 
Nkom (1997) correctly observes that one of the most profound consequences of colonialism was the suppression, distortion, degradation and destruction of African indigenous cultural systems and their deliberate and gradual replacement with western cultural values, philosophical outlooks and ways of doing things. This western influence on African culture has affected our development and internal social order. It has constituted a stumbling block in the way of African development policies and ethos.

Historically, Ashiwaju and Areola (1995) argue that slave trade and colonialism have exercised powerful influences on African culture and development, starting sometime around 1050 A.D. with the Muslims trans-Saharan and trans-Indian ocean trades, and continuing with the European Trans-Atlantic trade which began about $450 \mathrm{AD}$ and dragged on until about 1850. The slave trade also ravaged Black African culture and development for over eight centuries.

At the same time, Nigerians were subjected overtly to Western cultural influences through the introduction of Christianity, and western-type of education. The export-oriented economy developed by the British led to the promotion of export products at the expense of food crop production and the traditional food culture. Western-type of towns presently seen in Nigeria, such as Enugu, Port Harcourt, Lagos, Kaduna, developed as centres of British administration, commerce, and religion and initiated the rural-urban migration which has since created in Nigerian towns serious development and social problems. It also encouraged the growth of the nuclear family system, with grave consequences for the training and upbringing of the growing population of young Nigerians. British-type of houses, dresses and general life style became the order of the day, particularly among the growing Western educated elite. The above historical analysis explains how Europe superimposed her culture on Nigerian traditional values and ethos and subsequently, underdeveloped Nigeria as a nation. How, therefore, do we talk about sustainable development when our culture in Nigeria has been kept under subjection.

Ashiwaju and Areola (1995) contend further that, British was not interested in the preservation of the cultural identity of her colonial peoples; she came to Nigeria with a strong belief in the superiority of her culture and civilization over the Black man. Her policy was thus to tolerate Nigerian customs and traditions in so far as they were not offensive to British notions of justice and humanity. Consequently, virtually all her treaties and agreements with the different Nigerian peoples stipulated the abolition of all customs and practices which the British found objectionable.

Cultural imperialism which is targeted by the West at dislodging Nigeria's indigenous culture is a calculated attempt at perpetuating dependency and sinking Nigeria further into a gulf of underdevelopment. Hall (1996) sees cultural imperialism as a term used by a number of Marxist thinkers to describe the effects of the distribution of Western Mass Media throughout the world. Critics argue that the mass media of the United States (US) spread bourgeois values and thus indoctrinate people, particularly those in the Third World with capitalist ideology. Reinforcing this position, Nnonyelu in Ojiakor and Unachukwu (1996) states that western mass media generally have been used to create alien consumer culture, among the people of Nigeria.

Consumer societies, through the use of Western media, have also been created in Nigeria with life styles, values, tastes and aspirations based upon the models and commodities of the western industrial countries. The conviction is that the victims of cultural imperialism will continue to be decided from outside, and, in this sense, the progress of Nigeria is retarded as its production patterns are fashioned out in accordance with the needs and values of an alien culture. In this way, the West has come to dominate the cultural, economic and political lives of the country and stood as hindrances to sustainable development. These arguments can easily be illustrated. The purpose of cultural imperialism is nothing other than to change our tastes in Nigeria from local products to foreign mostly Euro-American goods. This means, our consumption patterns and lifestyles will dictate that we serve as markets to Europe/America while our domestic production forces would be discouraged and eventually withered away. Thus the development of Europe/America will continue to ensure the underdevelopment of the African societies. At the same time, the process might ensure the near-total destruction of the productive forces of these societies. With heavy dependence on Europe and America, socio-economic and political sustainable development in Nigeria will always be difficult. 
Everywhere in Nigeria, and almost in all aspects of the people's lives, we see the crumbling of indigenous technology and values before its western counterpart. For Nigeria to develop sustainably and progress along social, political and economic lines there is need for a cultural revolution; there is need for a new information and communication order; there is need to challenge the cultural imperialism of the West and their manipulative hypotheses and dominant paradigms. This revolution should, of necessity, face American and European cultural imperialism camouflaged in its exotic language philosophy and one- way traffic media ideology. This revolution will open a fresh chapter for sustainable development in Nigeria.

\title{
Sustainable Development
}

We shall consider the concept of development before elucidating what sustainability entails. While trying to define development, we need to bear in mind that it could mean or attract different interpretations to different people. In the past, people talked of development in relation to economic growth with emphasis on per capital income and gross national product. Today, development could mean more than it is defined above. In this regard, Goulet (1975) maintains that development is not a cluster of benefits given to people in need but rather a process, by which a populace acquires a greater mastery over its own destiny.

Guitierrez (1973) also sees development as liberation. He is of the view that real development can only happen when people have control over resources and have been fully liberated from the oppressive forces and are able to have full development of the human personality that will make them take control over their lives. Similarly, Nkom (1997) comments that:

\begin{abstract}
development, regardless of how it is defined, ultimately entails an attempt to build a "better" society; a society characterized by greater material prosperity and better life chances for the majority of the population; a society characterized by significant improvements in the people's capacity to understand, control and transform their environment for their own good and that of humanity in general; a society which opens up new opportunities for personal upliftment and cultural fulfillment; and a society in which creativity, productivity, fairness and popular participations are enhanced.
\end{abstract}

Sustainable development, on the other hand, entered the development discourse in the early 1970s. The 1972 UN Stockhom Conference on the Human Environment may be argued to be the first International Conference that brought the concept of sustainability to the international arena. However, Langhelle (1999) observes that there is a general consensus in the literature that it was the 1987 World Commission on Environment and Development (NCED) that was largely responsible for providing the normative conceptual bridge between environmental concerns and development outcomes.

Sustainable Development was further legitimized following the United Nations Conference on Environment and Development held in Rio de Janeiro; Brazil in 1992; the UN Conference on Sustainable Development held in 1993; and the World Summit for Sustainable Development held in Johannesburg in 2002. These conferences facilitated the globalization of the concept and the establishment of an international consensus on the concept of Sustainable Development. World Commission on Environment and Development therefore defines sustainable development:

as development that seeks to meet the needs and aspirations of the present without compromising the ability to meet those of the future. It is a process in which the exploitation of resources, the direction of investments, the orientation of technological development and institutional change are all in harmony to enhance both current and future potential to meet human needs and aspirations. 
Okwori (2004) sees sustainable development as an embodiment of a process of development that is socially responsive and just. It acknowledges the magnitude of poverty, exploitation, disempowerment and inequality that exists within communities, classes, countries and between nations and therefore, seeks to find lasting solutions to them without destroying the future. Sustainable development recognizes the world as an ecosystem. Sustainable development embraces need, satisfaction, popular participation, self-reliance, and use of appropriate technology, human and democratic rights, ecological integrity and cultural dynamics.

Nurse (2006) argues that Sustainable Development has traditionally been focussed on an environmentalism framework that gives priority to the issue of ecological degradation. One can safely argue that environmental concerns constitute the cornerstone of Sustainable Development. Until recently, Sustainable Development was viewed solely through the lens of the environmentalist but as the concept has matured, increasing emphasis has been placed on its interconnection to social and economic contexts of development. In view of this, Bell (2003) notes that the contemporary mainstream notions of Sustainable Development portray it as a tri-dimensional concept featuring the interface between environment, economic, and social sustainability. Munro (1995) states that economic sustainability reflects the need to strike a balance between costs and benefits of economic activities. Economic progress should not be made at the expense of inter-generational equity. Therefore, resources should not be exploited to the extent that their re-generative ability is compromised.

Social Sustainability on the other hand, according to Munro (1995), relates to the maintenance of political and community values. Social values and norms, being largely intangible, relate to the ethics, value systems, language, education, work attitudes and class system that influence societal relations. Social sustainability also seeks to satisfy the basic human needs within the society such as food, clothing, health, and shelter. The Sustainability of social needs and values alludes to the quality of growth that occurs in the economy.

In view of the above discussion, our location of cultural imperatives in this paper shall be within the tridimensional concepts of social, economic and environmental sustainability of development. Cultures, in all its dimensions, are a fundamental component of sustainable development. As a sector of activity, through tangible and intangible heritage, creative industries, and various forms of artistic expressions, culture is a powerful contributor to economic development, social stability and environmental protection. Let us now see how culture can contribute to the three dimensional concepts of sustainable development with examples drawn from local setting.

\section{Culture, Social and Economic Sustainability}

There is a close relationship between culture and social development. Cultural studies help to discover new understanding of the relationship between man and society. According to Akinsola (2011), Culture as a development tool contributes towards building social networks and trusts in the community, and helps create a sense of place and occasions for sociability that draws people together who might not otherwise be engaged in constructive social activities. Culture encourages grassroots social activists, local organizations, and residents to take an active role in community decision-making, political activities as well as to take ownership over their own community resources and identity. Culture as a development tool increases the level of civic discourse between artists, cultural groups, and community residents by providing opportunities and experiences that inspire, provoke, and facilitate discourse. This creates a collaborative atmosphere in which the arts sector can engage and forge stronger partnerships with others, including government, business, and the broader community.

Cultures are seen as both development and communicative tools in communities, organizations and institutions, as they increase the effectiveness of interactions, exchanges, researches, policies, and actions toward social development and sustainability. They offer an opportunity to engage in collective, collaborative activities, and enable the communities to become more publicly involved and active in 
socio- political processes. However, for culture to effectively serve as a vehicle of development, it uses a lot of tools to achieve its purposes. Some of the cultural tools include arts, religion, language and communication. It is therefore, not enough to talk about culture and social development without recourse to some machinery that drive culture itself especially communication. Communication is a product and tool of culture. A good cultural strategy must therefore, use communication to articulate development aspirations, propose new development directions and help people realize their potentials as creators of development. Communication leverages culture and development in several ways.

Culture produces communication, and no doubt, effective cultural communication is indispensable to social development sustainability. Communication has been argued to be a veritable vehicle for social cohesion and stability. Okwori (2013) argues that communication can indeed be seen as the most vital cultural tool for social planning and visioning. Thus in societies where communication in its varied forms have not been allowed to establish and take root as the vehicle for mobilizing the interactive processes of society, such societies have failed to develop no matter how sound, how good their social plans and visions look on paper. Social plans or visions are nothing but symbols on paper unless people are made aware of them and implement them. The process of being aware of visions and plans are the domain of operation of communication systems.

As a tool of culture, Fraser and Villet in Balit (2004) validate the contribution of communication to social development or visioning process by restating that: "If development can be seen as a fabric woven out of the activities of millions of people, communication represents the essential thread that binds them together. A development strategy that uses communication approaches reveals people's underlying attitudes and traditional wisdom to help people to adapt their views and to acquire new knowledge and skills and spread new social messages to large audiences.

The planned use of communication techniques, activities and media gives people powerful tools both to experience change and actually to guide it. An intensified exchange of ideas among all sectors of society can lead to the greater involvement of people in a common cause. This is a fundamental requirement for a sustainable change. However, communication as a cultural tool for social development goes beyond the everyday use of the mass media to inform, educate, enlighten and entertain, (Baran, 2003). It goes beyond the 'one-way' 'top-down' flow of information from government, policy-makers or agencies to the generality of the people but includes a more nuanced process of deliberating, sharing, participating and ensuring inclusiveness (Srampickal, 2006). It includes the totality of using communication in its cultural context for planning, implementing, and evaluating reforms; energizing people in constructive dialogue and promoting participation in public debate. It is a participatory communication framework that involves processes of engagement, exchange of information and resources and the capacities that enable understanding, negotiation and decision-making.

This kind of communication is effective for social planning and visioning and can help to keep the vision for change in focus. Participatory communication in the context of sustainable social change does not just mean providing more information to poor people. It means giving them voice. It means enabling them to participate actively in development activities aimed at their wellbeing. It involves a dialogue in which power holders listen to, respect and use the knowledge and views of the people. This type of communication should therefore, be an integral and endemic part of social development process.

According to Jegede (2010), Participatory communication entails a democratization of the structure of communication systems. It includes for example, a two-way and horizontal approach, a multi-media strategy which includes interpersonal communication strategies and community media arts such as local poetry, communal meetings, festivals, drama, discussions, story-telling, local songs/ music, interactive video, community radio, community TV, local newspaper, proverbs, folktales, sayings, home visits, exhibitions, role-playing, debates, visioning sessions, popular theatre, Participatory Learning and Action, transects, mapping, folk dance, Venn diagrams, riddles and jokes, just to mention a few. They are passed from one generation to another. Some of these communication strategies are found in almost every village and local settlement in Africa. If these forms of communication are used to convey change message and fully immersed in social development process, they may effectively influence the lives of the people and stimulate a sustainable social change. 
Language is another veritable tool that culture employs to stimulate sustainable social development. Language is not just a means of communication but also a carrier of culture. A discussion on social development and sustainability cannot be sufficient without recourse to language. Although, language is an important element of culture but we intend to examine it separately because of its strength even though, our perspective of it is from the local use. In view of this, Jegede (2010) argues that language is an important factor in social development intervention. Language is used among humans to establish, adjust and maintain interpersonal relationships and convey ideas and notions that are believed to be in the overall interest of a group, institution or community. This, in effect, demonstrates that language is a form of action, which can generate counter actions and reactions in forms other than language. Fairclough (1989) also argues that ideologies are closely linked to power and language because language use is a demonstration of power. Language has often been used as a medium of domination and social force; it has often been used as a political and social tool hence it plays a significant role in human actions and social development.

Good use of language in communication activity paves a way for social development and its ineffective use could make a shipwreck of the entire intervention process. If the whole nation is covered by satellite, the message of development it brings will not be open and transparent to the people unless programmes are conducted in their local languages. Citizens in Nigeria are both united and divided by the languages they speak. The dynamic nature of interrelationship between language, communication and sustainable social change has to be recognized by development agencies.

Okwori (2013) observes that the developing countries of the world especially Nigeria are multilingual, multi-ethnic and multicultural. Human resources development and change communication is effectively possible through the use of local languages. Effective use of language as a means of communication therefore, becomes the heart of change. Creating awareness and participating in the visioning and planning processes severely implicate language. The issue of language remains a sore point in the discourses of development in Africa. It is implicated in the myriad of problems besetting African development. It is implicated in our acute dependency syndrome and inability to be truly independent. Yet, it is a torchy issue that divides and sends us all to the trenches of ethnic sedimentation.

It is also in the domain of language that the relationship between culture and communication becomes completely blurred. Most of the African countries have foreign languages as their national, official and formal modes of expression. The arguments for and against this historical accident are quite strong. What we cannot however discountenance is that we are enmeshed in it and there seems to be no easy way out. To compound these, is the plethora of languages and cultures in Africa, Nigeria alone boasts of over 370 distinct languages that are not mutually intelligible. Yet language is central to socio-economic planning and visioning because, it remains the greatest purveyor of culture and the expression of communication.

It is very relevant to point out that language, an essential cultural tool, helps to facilitate useful dialogues which are needed to achieve social integration especially in Nigeria where cultural diversity predominates. Reinforcing this position, the UN Educational, Scientific and Cultural Organization (2009) contends that language as a cultural tool creates dialogue which is not only instrumental to creating mutual appreciation of diversity among cultures and constructive engagement but also promotes mutual understanding, knowledge, reconciliation and peace, which are essential for social stability and development of the Nigerian society. We shall however concretely illustrate how language and other aspects of culture can be used to promote social development in Nigeria especially in the area of health.

It may be quite revealing to point out that there have been several challenges in the area of health in Nigeria. In view of the problems associated with the health sector in Nigeria, the Department for International Development (DFID) has been supporting the re-establishment of primary health care services in a number of Nigerian states since 2002 through its investment in the Partnerships for Transforming Health Systems (PATHS) Programmes. The programmes, according to PATHS 2 Programme Memorandum (2007), have helped deliver extensive Federal Health reforms and impressive improvements to health services in the supported states.

The PATHS 2 health promotion programme was launched in August 2008. According to the Inception 
Review Report (2008), the Partnership for Transforming Health Systems 2 (PATHS 2) has set itself the ambitious goal of improving the health system and delivering sustainable change in common health problems starting with six states across Nigeria. PATHS 2 is designed to support Health systems reforms not only in terms of enhancing the Nigerian government's planning and delivery by building capacity and improving effectiveness within the health sector but also to drive change from beyond the service delivery front.

In fact, PATHS 2 is built around five separate Outputs (Outputs 1-5). Each of the Outputs has its unique goals and objectives. This paper is particularly interested in Output 5 because it is the communication strand of the entire PATHS 2 project. At this point, it is relevant to give Output 5 of PATHS 2 project some explanation in order to effectively understand the various but related issues involved in it. According to the PATHS 2 Inception Phase Report (2008), the goal of Output 5 of PATHS 2 is geared towards strengthening the capacity of citizens to make informed choices about prevention, treatment and care for priority health conditions.

The rationale for this goal is that to date, audiences in Nigeria have been swamped by a message culture which in the context of health, tend to tell people what is good for them and generally has been rather didactic in nature. The assumption is that, if people know about risk factors for diseases and about ways to minimize the risk of illness, they will take desired actions. A new approach to communicate health is therefore, needed. The core value of effective communication is the need to find out first what citizens (audiences) already know, think, feel or aspire to achieve. Output 5 at federal level and the focal states focused on introducing this new approach to communication system through the introduction of the programme: 'Ask Nigeria media polling'.

Output 5 emphasized engaging audiences in an interactive fashion and designed to influence demand for quality health services in Nigeria. At the centre of every component of output 5 strategies is the question of delivering communications outputs across all platforms and genres throughout Nigeria. However, our pre-occupation in this paper is how Output 5's health communication intervention was conducted from the cultural/ linguistic perspective to foster social development.

In fact, PATHS 2 Communication Research Specialist clarified this position. According to him:

Output 5 believes strongly in the indigenous languages of the people.
The local language use started right from the beginning of Output 5
research activity. Allour initial advocacy visits and consultative meetings
were conducted in native languages with the use of local interpreters to
announce the programme purpose, solicit for cooperation and support
to build trust among the community stakeholders (Olanorin/Jegedel
personal interview. $15^{\text {th }}$ October 2009).

Still continuing, the PATHS 2 Communication Research Specialist added that the use of local languages immensely helped the Output 5 team (although utilizing the local interpreters) to explain the basic ideas behind Output 5 such as the nature of the programme, its meaning, its purpose, its source, benefits and the role expected of the community stakeholders in the course of the programme. This explanation was carefully and patiently done in a concise, clear, simple, open and transparent manner. This linguistic factor helped in creating much needed rapport between the project team and the communities under investigation.

Furthermore, the selection process of the communities' stakeholders was also transparently conducted using the people's languages. The selection of the stakeholders in their different categories was essentially an interactive session. The stakeholders or community participants were interviewed and asked to verbally produce their Bio-personal data such as names, ages, places of origin, status, occupations, religions, marital status, number of children, etc. All these information reflecting personal status were gathered at the selection stage using their local languages. 
At the baseline survey, indigenous languages became very imperative for the team to be able to carry the native people along effectively. Most of the people could not speak English Language. The success of the baseline survey heavily rested on the use of indigenous languages. The local interpreters and translators played a crucial role in this setting. For example, the focus group discussions, in-depth interviews and other sessions were conducted in languages that the native people speak and understand. The use of local languages also enhanced people's effective participation and ability to generate much needed information on health issue.

The PATHS 2 Output 5 has at its heart participation which was facilitated by the effective utilization of the indigenous languages. The Output 5 team conducted several sessions with different groups of stakeholders such as the youths, women, religious leaders, physically challenged people, traditional leaders, children and parents using the local languages they understand. The effective language use in Output 5 helped immensely in realizing the aim and objectives of the programme and strengthening the envisioned social change.

Having said this, it is pertinent to discuss other core aspects of culture. Language is though tied to culture and constitutes an important element of culture. But language is not the only issue in the general discourse of culture. Culture goes beyond the linguistic factor. Culture is the totality of people's way of life. In this regard, our pre-occupation is to explain how Output 5 was conducted with the culture of the local people in mind, language factor now apart. Cultural factor is a strong factor to be borne in mind in the process of conducting social intervention in an open, transparent, participatory, lucid and acceptable way. Any development process that is articulated in an alien culture not understandable and transparent to the local people is bound to fail and produce poor results. To build open, transparent information and communication systems for Output 5 's health communication intervention, the issue of indigenous culture is a sine-qua-non.

However, the discussion of culture in this paper will also reflect areas of sensitivity in terms of: norms and values, taboos, habits and customs, attitudes and behaviours of the communities. In this regard, the PATHS 2 Communication Consultant maintained that Output 5 is gender and culture sensitive. The Output 5 was conducted very carefully in a way that it did not violate the religious, social and moral rights of the communal people. According to him, culture strongly found its due place in Output 5 right from the very beginning.

The Output 5 team did not just dabble into any community without preliminary investigation about sociocultural, political and philosophical make-up of such a community. The team took time to investigate all the communities, finding out their histories, nature of the people themselves, the languages they speak, their livelihoods, aspirations, local problems, resources, beliefs, value system, settlement patterns, predominant occupations, mode of relationships, taboos, norms, mores, structure of leadership, religious practices, modes of worship, communal biases and prejudices.

These preliminary investigations were carefully carried out using a strong observational tool coupled with advocacy and consultative meetings with the relevant key stakeholders. In addition to this, most of the communities visited in the four states are agrarian regions where farming practices, petty trading and small-scale local manufacturing are predominant. Output 5 team was careful enough not to allow communication research interfere with or disrupt all these economic activities that constitute the means of their livelihood. Baseline assessment was carried out at people's convenience.

In his own contribution to this discussion, PATHS 2 Communication Research Specialist said that all the communities under investigation in the four focal states have their own different peculiarities and religiocultural patterns. Some communities are predominantly Islamic regions especially Kano and Jigawa States. Kaduna State is a mixture of the two religions while Enugu State is predominantly noted for Christianity. Output 5 was religion- sensitive and conducted in a way not offensive to the religious practices of the people. For example, on customary and religious ground, some communities in Jigawa State in Nigeria did not want discussion on teenage pregnancy issue. Discussions on this teenage pregnancy issue were therefore, cleverly and tactfully handled by Output 5 team without provocations and offence. The research 
team's movements were properly guided and coordinated with the assistance of the available communitybased organizations (CBOs) and other communal opinion leaders thus preventing the team from straying to places declared out of bounds especially to strangers.

The opinion leaders and the existing $\mathrm{CBO}$ s in the various communities under investigation became an effective tool in the hands of the Output 5 research team as they led the way and took the lead in most of the activities. This group took time to explain the communal taboos, beliefs, traditional laws, mores, value system and norms to the research team. This immensely helped to keep the team on toes and to take precautions. At the baseline survey, this group served as interpreters and was instrumental in mobilizing local support for the team. Summarily, the activities of the CBOs and local opinion leaders helped the team tremendously to conduct effective communication research along the path of people's culture without any crisis. However, despite the active involvement of some stakeholders in the entire participatory communication process, the PATHS 2 Communication Research Specialist lamented that there were lots of challenges and frustrations in dealing with some communities in Jigawa State.

Based on cultural and religious factors, women's participation was highly limited. Conversely, he noted that men and youths are more accustomed to engaging in the public area and the CBOs selected to facilitate the proceedings were highly dominated by men. Even though, women were brought into the $\mathrm{CBOs}$ later, their participation was limited. Most of them were often expected to remain at home in the private sphere either as purdahs or housewives. From the foregoing, it therefore means that a lot of advocacy campaigns for women participation in development have to be conducted on the religion and culture that appear to place some restrictions on women. Until equal representations and balance are achieved in the participation of both men and women in social development processes, the possibility of using communication research to effect a lasting change may be elusive. However, during the baseline survey, the Output 5 team ensured that the meetings, interviews, and discussions were not conducted in secluded locations especially with women and young girls to avoid unnecessary suspicion from the natives. Similarly, all the research activities were carried out in the day time and in open places where persons could be observed from afar. The research team made sure no member of the community was forced to engage in any activity against his or her will. All the characteristics and limitations of each participant were carefully noted, handled and managed.

Over and above all, dress code was duly observed by the Output 5 research team, each wearing clothes that are modest, comfortable and acceptable. All the illustrations, cases, examples and questions on health were familiar things usually found within their immediate environment and were all articulated in their local languages. All these were done accordingly in order not to contend against people's culture or do things that will prevent Output 5 from realizing its goal and objectives/ In view of the above, it is relevant to say that the role of culture in social sustainability of development cannot be overemphasized. Based on this, Nkom (1997) asserts that while science and technology may be important tools for the realization of a better Nigeria, it is the culture and philosophical outlook of the people which give content, meaning and direction to the socio-political vision of the desirable society. It is culture that gives meaning to a people's social and developmental aspirations and provides substance and direction to their institutional and programmatic agenda. If properly mobilized, culture can give impetus to social development and act as a springboard that releases the creativity, energy and dynamic action of the people for sustainable socio-political transformation.

Every form of development should naturally and inevitably involve an element of cultural transformation. Culture is, after all, the dynamic outcome of a society's struggle to harness and tap the resources of its environment for its social welfare and of its material reproduction and harmonising the relationship between individuals and groups in the society and between that society and other neighbouring societies. To this end, there is, in essence, an organic relationship between culture and social sustainability.

On the issue of culture and economic sustainability, it is relevant to point out that culture occupies a central place in economic growth and sustainability. The cultural sector plays a dual role in that, it is an arena for identity formation as well as an economic sector with growth potential serving as a key driver of the new digital and intellectual property economy in Nigeria. Reinforcing this view, Nurse (2002) reveals that: 


\begin{abstract}
The cultural industries are well organized as a means of artistic expression and symbols of national and regional identity. They describe the role of cultural entrepreneurs and arts enterprises, for profit as well as not-for-profit in the production, distribution and consumption of film, $T V$, books, music, theatre, dance, visual arts, masquerade, multimedia, animation and so on. The cultural sector is not just a commercial arena, it is an aesthetic and economic space where spiritual values, psychic meaning and bodily pleasures are displayed, enacted and represented.
\end{abstract}

From developmental perspective in Nigeria, cultural production is an important area for investment and a means of bolstering cultural identity and economic advancement. It also aids the diversification effort in mono-cultural economies that are overly reliant on a narrow base of traditional and non-traditional exports. The cultural industry is making an increased contribution to the Gross Domestic Product (GDP), exports and generating new domestic form of employment in Nigeria thus creating a reasonable expansion within the economic system. Cultural sector is a powerful national economic engine. In the 1990s, Nurse (2002) observes that the cultural industries in Nigeria grew at an annual rate twice than of service industries and three times than of manufacturing in Nigeria. Cultural industry facilitates a more competitive development platform and it constitutes a critical resource in the move towards creating sustainable development in the economic context.

Arguing along economic line, Munro (2006) believes that the cultural industry is one of the fastest growing sectors of the Nigeria's economy. This growth is accounted for by rapid techno-economic change in products; distribution and marketing; the increasing commercialisation of intellectual property particularly copyright; the shift towards a post-industrial economy where personal, recreational and audio-visual services have expanded as a hare of the economy; the strong cross promotional linkages with sectors like festival tourism / the convergence of media; the increasing concentration of large firms and the expansive growth of the digital economy (e.g. the Internet and Commerce) that allows for easier production, distribution, consumption as well as infringement of cultural industries sector.

In addition to the above, the United Nations Educational, Scientific and Cultural Organization (2009) reports that the culturally embedded livelihood practices in the African countries (including Nigeria) help retain local knowledge and generate employment opportunities while also enabling local economic development. These cultural practices may vary from building crafts to agriculture, local festivals and natural resource management. In the same vein, cultural tourism, infrastructure and institutions such as universities, polytechnics, museums, cultural centres, cinemas, theatres, craft centres, and other such institutions in Nigeria are significant generators of knowledge, employment and revenues thus creating a terrain of economic development and sustainability. For example, (IIED, 2012) observes that the African traditional festivals are a way of generating economic development. Celebration of festivals in Ghana for instance, is an ancient practice. Generally these were associated with planting and harvest time or with honouring the ancestors. The festivals serve for thanksgiving to the Supreme Being (God), and pacification of the gods as well as the ancestors, an occasion for strengthening people spiritually and economically. The occasion also offers citizens of the area who now live elsewhere the opportunity to visit home and join their families. In the course of these visits, outstanding disputes and misunderstandings on economic and political matters can be settled.

Culturally, the festival helps to transmit, conserve, and project the culture of the traditional area. The occasion is also used to teach the traditional dances, songs, drumming, and art of the area. Festivals attract tourists into the community and may earn some huge income for local development of the traditional area. Politically, chiefs use the festivals as a means to achieve the principle of governance by consent. This they do by giving accounts of the events of the previous year and making projections for the coming year. It allows the people of a community the chance to correct past mistakes and to plan the future. The festivals also promote commercial activities within the communities where sundry goods are sold and different services provided by the natives and neighbouring communities and this helps in boosting local economies. The festivals are an opportunity for subjects and sub-chiefs to pay homage to, and renew their 
loyalty to the paramount chief. Chiefs and their people also use them to appeal for funds for development projects that are capable of advancing local economies. Most times the funds generated at festivals are used to train the youths, empowering them and building their capacity for economic viability and productivity.

\section{Culture as a Vehicle for Environmental Sustainability}

Environmental sustainability is not only a concept but also a process and an end. It demands an understanding of development imperatives and attitude of the mind to make it work to support human security and peace through conservation of natural resources for sustenance of livelihoods. It is also an attitude of the mind which gives direction to all activities that have impact on the environment. Culture helps in enhancing environmental sustainability. Nurse (2006) believes that environmental and global challenges such as conflicts, wars, terrorism, disasters, endemic poverty, pollution, critical financial crisis, rapid urbanization and degradation have rendered people all the more vulnerable to change and the impact of natural disasters are fast leading to the loss of local resources. Where all these exist, culture as a constructive force, builds resiliency by reinforcing the abilities of the people to be innovative and creative especially in the adversity of disasters, conflicts and wars.

Nurse (2006) notes that intercultural dialogue can be deployed to bring about peace and possibilities of reconciliation in the events of conflict. Following a disaster, culture in all its forms could help communities reconstruct their disrupted lives and restore psychological well-being. More importantly, Nurse (2006) contends that a variety of current environmental challenges such as depleting water sources, shrinking forest covers and disappearing species, rooted in a disregard for the environment, may be addressed by positive practices embedded in local cultures that value a balance between natural and human worlds. In addition, the United Nations Educational, Scientific and Cultural Organization (2009) notes that values and beliefs shape the relationship of a people to their natural environment and the ways they manage and impact on it. Accumulated indigenous knowledge, cultural values and the community practices of environmental management are fundamental resources towards achieving environmental sustainability and constitute essential factors for the survival of the place and people. Heightened awareness of this indigenous knowledge enables people to become protectors of their own environment.

What does indigenous knowledge actually mean? Okwori (2013) takes Indigenous knowledge to be those practices, knowledge systems, values, attitudes, artistic and cultural forms of expression, developed over time by a people in response to the challenges of their environment and survival. They are mostly "held in peoples' heads, passed down from one generation to the next by words of mouth" and through enactment of repeated performances. Indigenous knowledge is integral to effective environmental sustainability and empowerment of local communities in Africa, in a way that the mainstream media is not. Indigenous knowledge systems are easily handled by the people, they engender discussion and communication among them, and make them retain control over the media, and ideas, decisions and solutions arrived at as a result of programme encounter. When indigenous knowledge is ignored, the result of environmental development effort may be woeful. The value of using indigenous communication strategies therefore, is, "that rather than introducing new 'bits' of information into a culture regardless of pre-existing knowledge and experience, new information can be introduced in a context of existing associations, experiences and concerns" (Nichter 1991).

Indigenous knowledge is linked to the recovery and protection of environmental health, history, and the culture of sustainability in society. It is linked to traditional practices through celebrating local and regional histories and passing down cultural values to future generations. Storytelling, drama, proverbs, poetry, folk media and other forms of eco-arts are often discussed as forms of indigenous knowledge and traditional practices capable of keeping memory alive; celebrating our history or identity; generating lessons about how to act effectively, inspiring action and serving to synthesize the past with the present for the benefit of the future. Eco-arts generally, as a form of indigenous knowledge, have a tremendous role to play in environmental sustainability. In this connection, Duxbury and Gillette (2007) argue that we must acknowledge the role of culture in environmental sustainability from the perspective of eco-arts. Some eco- artists find inspiration from the environment, while others use art to tackle critical environmental 
issues. In recent years, relationships between some artists and environmentalists have grown stronger, based on their similar values and worldviews toward the preservation and protection of the environment. For instance, Duxbury and Gillette (2007) note that Eco-arts as a form of indigenous knowledge can be used to promote environmental sustainability in the following ways. For example, eco-arts: inform people about environmental issues and protection; blend creativity with environmental projects and planning in communities; and promote a healthy relationship with the land and living in harmony with nature, inspired by a growing interest in indigenous practices.

In addition, Eco-arts projects are often collaborations initiated by artists, environmental groups, local musicians, or communities and "tend to be connected to a sense of place and spring from local concerns with polluted waters, social erosion, habitat loss, and reclamation of post-industrial sites and the remnants of resource culture as a Key Dimension of Sustainability - Duxbury \& Gillette (2007). Artists who are engaged in cultural sustainability often see their creative projects as an environmental practice. Carruthers, (2006) similarly highlights some of the ways by which arts as a cultural tool can be used to enhance environmental sustainability. For example, they help to: retain and preserve heritage buildings; Support ecologically sustainable art products and services; promote environment-friendly craft products; use under-utilized space for arts activity; disseminate information on environmental sustainability; protect green space and parks; inform community residents about environmental issues and problems facing the globe; and increase the development of eco-art practices.

In the furtherance of this discussion, it is pertinent to explicate how indigenous knowledge can be helpful in strengthening environmental issues. An example of how indigenous knowledge especially drama can contribute to environmental change is what Okwori (2013) terms "Conquer good work." According to him, in the late nineties, the Institute for Agricultural Research (IAR), based in Ahmadu Bello University $(A B U)$, Zaria, Nigeria introduced the short stalk sorghum variety after years of research. This variety yields thrice as much as the traditional long stalk.

Farmers were enthusiastically encouraged to accept this new variety. Many farmers accepted and tried it. The yield was quite plentiful indeed, but after the first year most of the farmers that tried out the new sorghum variety rejected it. The IAR consulted the drama programme in ABU to use community theatre to find out the reasons for the rejection: using a series of skits, the drama section encouraged farmers to enter the story to reconstruct the sorghum variety that was desirable and why. It turned out that the reason for the rejection was because after harvesting, the long stalk of traditional variety was used for a range of things: walls, barns, crop holders, doors and so on. The finding made IAR to go back to the drawing board.

There is therefore an understandable interest in the viability of indigenous knowledge to environmental development more especially as the classical strategies are proving ineffective. The search for an alternative is predicated on the need to make development participatory and sustainable. One of the key demands of this alternative is the utilization of the knowledge systems of development subjects. For example, based on knowledge developed over thousands of years, Okwori (2013) reports that, peasants in the Peruvian Andes have been practicing and managing a diversified agricultural system of raising livestock, growing tubers, cereals and vegetables in valleys and on steep mountain slopes. The introduction of "modern" farming methods like the indiscriminate use of chemical fertilizers have not only destroyed this knowledge but have led to toxic contamination and soil infertility. To salvage the situation, Grupo Talpuy, founded in 1979 in Huancayo, Peru works to "demonstrate that indigenous practices often bring results equal or superior to those of commercial agriculture, and without ecological degradation or dependency". The success of Grupo's practice has brought about agricultural sustainability made possible through indigenous knowledge

It is noteworthy to state that, culture, in all its multiple forms, is essential to addressing global and environmental challenges through its role in economic growth, in human development (as a storehouse of environmental knowledge) and serves as a symbolic force to bringing stability and meaning to communities everywhere. Cultures of inclusiveness and environmental ethics enable even the most marginalized 
individuals and groups to participate in development processes and benefit from them. Culture provides solutions that respond to local specificities as a driver of environmental sustainability in its own right as well as a desirable outcome of development efforts.

\section{Conclusion}

Facilitating development through the perspective of culture is an empowering process for the society, in which cultural awakening, language, communication, folklore, arts, creation of unity, participatory actions are not only important elements but the thrust of ensuring that the development is sustainable. In this regard, development should form a continuous process of cultural communication, which is the central element in endogenous and indigenous development. For Nigeria to develop sustainably there is a need to appreciate our cultural values and heritage. The country should watch out for the Western cultural ideologies which in the main have so far created culture misfits and fragmentations that are hardly useful for meaningful sustainable development. African culture is beautiful and potent enough to usher in development. Nigeria must therefore, give it a place in the scheme of things. The health communication interventions and experiments in PATHS 2 within the context of culture, as earlier explicated in this paper, is a point in case. The deployment of local colours and resources especially with regards to indigenous languages, local talents, folkloric communication, research and participation of local people in the development process is a laudable effort even though the intervention did not go without its own challenges. Culture occupies a central place in development and sustainability discourse.

In view of the above, when we talk about development, scholars should think beyond the economic, social and political aspects of the term. High regard should be placed on cultural liberation. Culture has daily played an invisible role in determining our customs, values, morals and growth in the society. If we as a nation truly aspire freedom from the shackles of underdevelopment, there is an urgent need to break away from the confines of western cultural systems evident in our dressing, language, music, artwork, attitude to innovations and search for that which made us proud to be Nigerians before colonization. For the liberation process to be triggered off, one should address the ugly trend that makes western countries inventors of cultural and technological initiatives that are ultimately consumed by the Nigerian nation.

A major step in addressing the issue of a Nigerian cultural policy is commissioning professionals in the area of conservation of our Nigerian heritage to present an inventory of our works of art, art forms, folk history or oral tradition and practices. Such documentation should take into account the element of cultural contamination caused by mingling with people from diverse cultures or ways of life. There is also a need to formulate attractive strategies to promote interest and awareness among international tourists, regional travels and even local inhabitants about a nation's cultural heritage. When properly managed, culture could be an important vehicle for intercultural exchanges and sustainable development.

To this end, any nation that so haplessly neglects its own development paradigms to welcome alien outlooks will experience such progressive disintegration that only judiciously applied medication and therapy can repair. A leadership interested in the technological, political and economic advancement or development of its nation should never disregard the role of culture. A nation consciously or unconsciously allowing for a deriding of its cultural identity would ultimately lose some of the respect it would have received from the outside world. In addition, a search for and protection of our cultural heritage is the start point of any meaningful attempt at Nigerian cultural liberation and development- a Nigerian development that should begin with an identification of local condition as well as solutions for correcting these conditions, formulated by Nigerians for Nigerians. It must also be enunciated that for as long as Nigerians remain armchair recipients of western cultures, without learning to do things targeted at their awakening, the national sustainable development will persistently remain an illusion. To this end, if a sustainable development must take place in Nigeria in all ramifications, the centrality, preservation, and reconstruction of local culture should not be ignored. 


\section{References}

Akinsola, A D. (2011). Understanding African Cultures. Ibadan: AGABI Press Ltd.

An-Naim, A. (1990). "Problems of Universal Cultural Legitimacy for Human Rights in An-Naim, A. and Deng, F.M., (eds) Human Rights in Africa: Cross-Cultural Perspectives, The Brookings Institution, Washington, D.C.

Amadi, R. (1981). Administration and Development of Culture: The Nigerian Experience. Lagos: Federal Department of Agriculture.

Ashiwaju, G. \& Areola, O. (1995). Nigeria: The First 25 Years. Ibadan: Ibadan University Press.

Ayakoroma, B. F. (2011). Media and Culture in Nigeria's Sustainable Development: The NICO Initiative.

Balit, S. (2004). 'Communication for Isolated and Marginalized Groups: Blending the Old and the New', Balit@mclink.it.

Baran, S. J. (2003). An Introduction to Mass Communication: Media Literacy and Culture. $3^{\text {rd }}$. Edition. New York: McGraw Hill Companies.

Bell, S. (2003). Measuring Sustainability: Learning by Doing. London: Earthscan Publications Ltd.

Conguergood, D. (1992). "Health Theatre in Hmong Refugee Camp" in: T.H.E. World Stages Theatre In Health Education Issue Four, October 1992.

Culturelink (1996). Cultural Policy in Nigeria: IRMO/Culturelink. Retrieved from http://www.wwcd. org/policy/clink/Nigeria.html on 17-02-2016.

Duxbury, N. \& Gillette, E. (2007). Culture as a Key Dimension of Sustainability: Exploring Concepts, Themes, and Models. Creative City Network of Canada. Centre of Expertise on Culture and Communities. Working Paper 1.

Goulet, D. (1975). The Currel Choice: A New Concept in the Theory of Development. New York: Antheneym.

Geertz, C. (1973). The Interpretation of Culture., New York: Basic Books.

Guitierrez, G. (1978). An Introduction to the Study of Comparative Education. London: Heinemann Educational Books.

Hall, S. (1996). 'Culture, the Media and Ideological Effects'. London: Hutchinson.

Hagher, I. H. (1997). 'The Rise of Mass Political Awareness and the Fate of the Third Republic', Culture and Democracy. Zaria: ABU Press Limited.

Jegede, E. (2010). "The Heart of Change: Communication and Communication Use in PATHS2 and UNICEF Northwest, Nigeria, Unpublished PhD Dissertation, School of Postgraduate Studies, Ahmadu Bello University, Zaria.

Langhelle, O. (1999). Sustainable Development: Exploring the Ethics of Our Common Future. International Political Science Review.

Munro, D. (1995). Sustainability: Rhetoric or Reality? In A Sustainable World. International Centre for the Environment and Public. 
Musaazi, J. C. S. (1986). Planning and Development in Education - African Perspective'. London: Allen \& Unwin (Publishers) Ltd.

Mundy, P. and Compton, L. J. (1999). "Indigenous Communication and Indigenous Knowledge", Development Communication Report, No. 74, 1991/3, Clearing House on Development Communication, Arlington

Ngugi Wa Thiongo. (1972). Home Coming. London: Heinemann.

Nkom, S. (1997). 'Reflection on Culture and National Development in Nigeria in Culture and Democracy. Zaria: ABU Press Limited.

Nichter, M. (1991). "Analogy in Health Education: Using the Familiar to Explain the New", DCR, No. 74, 1991/3, Clearing House on Development Communication, Arlington.

Nnonyelu, A. U. (1997). 'Development Theories: Implication for Nigerian Development'. In Issues in Contemporary Nigeria Development Akwa: Nuel Centi (Nig.) Publishers.

Nurse, K. N. (2002). "Governance, Industrial Policy and the New Global Economy: The Case for Cultural Industries" in Cynthia Barrow-Giles and Don Marshall eds. Living at the Borderlines": Issues in Caribbean Sovereignty and Development Kingston: UWI Press.

Okwori, J. Z. (2013). Cultural Analysis as an Essentialising Architecture for Development Planning Faculty Seminar Presented to the Faculty of Art Ahmadu Bello University

Okwori, J. Z. (2004). 'Empowerment for sustainable development: The Popular Theatre Strategy'. PhD Thesis, Zaria, ABU.

PATHS 2 (2008). 'Inception Phase Report' Abuja: PATHS 2 Publication.

PATHS 2 (2007). Programme Memorandum Partnership for Transforming Health System 2' Abuja.

PATHS 2 Communication Research Specialist (Olanorin, Kayode), Personal Interview, $15^{\text {th }}$ October 2009. PATHS Office Abuja.

PATHS 2 Media Production Advisor, (Iliyasu Ibrahim) personal Interview, 15 $5^{\text {th }}$ October 2009. PATHS Office, Abuja.

PATHS 2 (2008). Development of Outline Communication Strategy' Abuja: PATHS 2 Publication.

Srampickal, J. S. J. (2006). “Development and Participatory Communication,” Communication Research Trend 25(2).

Seppala, P. \& Vaino-Mattila, A. (2000). Navigating Culture: A Roadmap to Culture and Development, Ministry of Foreign Affairs, Department of International Development Cooperation, Helsinki, Finland.

Soetan, R. O. (2001). Culture, Gender and Development. The Centre for Gender and Social Policy Studies OAU Ile-Ife. A Report submitted to the African Institute for Economic Development and Planning Dakar, Senegal.

Sofola, J. A. (1973). African Culture and the African Personality. Ibadan: African Resources Publishers.

The World Commission on Environment and Development (WCED) (1987). Our Common Future. Retrieved from http://www.un-documents.net/wced-ocf.htm on 17.02.2016 
The International Institute for Environment and Development (IIED), (2012). PARTICIPATORY LEARNING AND ACTION. London, UK: IIED

United Nations Educational Scientific and Cultural Organization (2009). Report on "The Power of Culture for Development."

Yere, J. K. (2007). The Role of Culture in Effective Human Resources Management: A Conceptual Framework'. In: Academy Journal of Marketing Research. Vol. 1 No. 3, ABU, Zaria: Marketing Academy of Nigeria.

\section{About the Author}

Dr. Emmanuel Jegede is a faculty in the Department of Theatre and Performing Arts, Ahmadu Bello University, Zaria, Nigeria. 